\title{
Financial Performance as Mediator on the Impact of Capital Structure, Wealth Structure, Financial Structure on Stock Price: The Case of The Indonesian Banking Sector
}

\author{
Andi Mansyur, Abd. Rahman Mus, Zainuddin Rahman, and Suriyanti Suriyanti
}

\begin{abstract}
This research examines the financial performance as a mediating variable in analyzing the capital structure, wealth structure, and financial structure of stock prices by using trade-off theory and signaling theory. This study uses 145 secondary data in the form of bank financial reports listed on the Indonesia Stock Exchange (IDX). Model testing uses structural equation (SEM) through the SmartPLS version 3.0 programs. The results of model testing show that capital structure and financial structure can reduce financial performance, wealth structure can improve financial performance. High financial performance cannot increase stock prices. The capital structure does not lower the stock price, the wealth structure raises the stock price, and the financial structure lowers the stock price. Financial performance does not mediate the effect of capital structure, wealth structure, and financial structure on stock prices.
\end{abstract}

Index Terms - Capital structure, wealth structure, financial structure, financial performance, stock price.

\section{INTRODUCTION}

The global financial crisis revived discussions about the importance of adequate bank capital. This is since around the world many banks fail, forcing their governments to pay for their capital [1]. A healthy financial system is needed in banks that regulate capital adequacy to withstand financial crisis shocks that result in losses in the banking sector [2], [3]. Capital structure is important because it is closely related to company value. Apart from this, the capital structure aims to minimize the cost of capital and maximize firm value [4].

This statement shows that the optimal capital structure decision is very important for a company to survive [5]. Wrong or low-quality decisions about capital structure can result in high costs of capital and financial risk and can reduce profitability. In the long term, it can result in decreased financial performance or company bankruptcy [6,7]. Optimal capital structure for bank institutions is very important. The optimal capital structure allows the bank to perform operations well [8]. Good bank operations can provide a buffer to absorb unexpected losses from their activities [9].

The efficiency and effectiveness of bank operations are

Published on September 30, 2020.

Andi Mansyur, Postgraduate School of Indonesian Muslim University

Makassar, Indonesia.

(e-mail: andimansyur@gmail.com)

Abd. Rahman Mus, Indonesian Muslim University Makassar, Indonesia

Zainuddin Rahman, Indonesian Muslim University Makassar, Indonesia.

Suriyanti Suriyanti, Indonesian Muslim University Makassar, Indonesia. highly dependent on what shapes their capital [10] Sufficient business capital is needed to be able to increase and expand the company's business [11]. The optimal proportion of the components of the capital structure affects positively; the company's financial performance, maximizing return on capital and minimizing financial risk [12].

Low leverage capital structure tends to increase profit margins, returns on assets, and equity [13]. The contribution of capital structure is positive but weak to the profitability of public sector banks [14], however, in other studies; it is found that there is a potential relationship between capital structure, ownership structure, and corporate governance on corporate financial performance [15].

The inconsistency of the findings is shown by other scholars, that the capital structure is not relevant to the financial performance and value of the bank [16]. This fact can also be shown that there is a negative relationship between total debt to return on equity and earnings per share [14].

Capital structure has a weak positive impact on financial performance [17]. There is an inverse relationship between capital structure as measured by long-term debt to equity ratio, total debt to equity ratio, and total debt to total assets ratio and financial performance [18]. The composition of the capital structure is a negative effect on the company's financial performance [19].

Wealth structure is a balance or comparison between fixed assets and total assets [20]. This statement is emphasized by other scholars that the wealth structure is the determination of how much the allocation of funds for each asset component, both in current assets and fixed assets [21]. Assets owned by the company both current assets and fixed assets affect company performance.

The financial structure as a way for companies to finance their assets. One element that needs attention is the extent to which the company is able to meet the needs of the funds used to operate and develop its business. The relationship between wealth structure and financial performance has been investigated by several researchers. There is a negative relationship between wealth structure and bank financial performance [22]. The wealth structure and capital structure partially is a negative effect on stock prices [23]. It is empirically found that the measure of firm wealth has a negative and significant impact on financial performance [24]. Different evidence shows that wealth growth has a significant positive relationship to earnings per share [14].

Financial structure is how banks fund their assets. Bank assets are funded with short-term, long-term debt, and shareholder capital, so that all sides of the assets of the 
balance sheet show the financial structure [24]. The financial structure reflects how the company's assets are spent. Thus, the financial structure reflects the balance between total foreign capital and the amount of capital itself. Poor financial stability will harm financial performance and stock prices.

Determining the financial structure is a matter of the composition of the funding that the bank will use, namely determining how much debt is used to help equity fund investments in assets [25]. Alternative sources of funding come from internal financing and external financing [26]. The use of external funds can be in the form of debt or the form of additional equity. The use of debt will lead to dependence on external parties and increase the company's financial risk [27]. The condition of the banking financial structure is described based on financial indicators such as; Debt to Total Asset Ratio (DAR), Equity to Asset Ratio (EAR), and Debt to Equity Ratio (DER).

Empirical evidence shows that the DER, DAR, EAR have a significant effect on Return on Equity (ROE) [20,28]. The financial does not affect structure as measured by DAR and DER has a positive effect on financial performance as measured by Return on Asset (ROA). Meanwhile, EAR does not affect on ROA [28]. The financial structure as measured by the Debt to Asset Ratio has no effect on stock prices [29].

A financial structure as measured by DER has a positive effect on stock prices [30]. DAR and DER have a significant effect on stock prices [31]. Banks that use high fixed assets will cause a large proportion of fixed costs to variable costs. Fixed asset funding sources that use fixed debt will increase fixed costs, thereby reducing the rate of return and increasing risk. The use of sources of funds to provide assets of large value will increase the fixed burden that will be borne by the bank.

The consequence of the use of high fixed assets is to make the bank's ability to generate operating profits smaller, the book value of a bank will decrease, which in turn will have an impact on the decline in banking stock prices [32]. A favorable bank financial performance gives rise to; creditor confidence in the bank's ability to fulfill obligations, provide guarantees to depositors regarding the security of deposits, reward shareholders in the form of dividends in return for invested funds, and provide job security guarantees to managers, and demonstrate the bank's ability to pay taxes to the state [33].

Stock Price is the selling value of shares formed based on the demand and supply of shares in the Indonesian stock exchange [34]. Stock trading transactions are based on the observations of investors on the company's performance in its operations.

The stock price is influenced by many factors including the condition of the company's financial performance. The high financial performance will have a positive effect on stock prices, that ROE has a positive and significant effect on stock prices [35], [36]. The stock price is likely to be high as predicted if the value of the liquidity ratio, asset management, debt management and profitability ratios looks good and these conditions continue in a stable manner [37].

The effect of financial performance on stock prices has been investigated by several researchers. However, research results also vary, including results that show that financial performance as measured by ROA and ROE has a positive effect on firm value [38]. Financial performance as measured by ROA and ROE has a positive effect on firm value [39]. However, with the use of other indicators for financial performance, such as Long term Debt Ratio (LDR) and Non Performing Loans (NPL), it is found that financial performance is a negative effect on firm value. Likewise, with the use of operating profit margin (OPM) and Nett profit margin (NPM) indicators, it is found that financial performance does not affect firm value [38].

\section{LITERATURE REVIEW}

\section{A. Stock price}

Shares are a piece of paper that shows the rights of the investor, namely the party who owns the paper to obtain a share of the prospects or assets of the organization that issues securities under various conditions that allow the investor to exercise his rights [40]. Shares are securities which are instruments of proof of ownership or participation of individuals or institutions in a banking institution. The share price is the price of a share that occurs on the stock market at a certain time determined by market players through the mechanism of demand and supply of shares that occurs in the capital market [41].

The stock market price is formed through the supply and demand mechanism in the capital market [42]. The cause of changing stock market prices is influenced by two factors, namely; Internal (fundamental) factors are factors that come from within the company and can be controlled by management, and external (non-fundamental) factors are factors caused by economic conditions such as; interest rates and government policies [43].

Apart from the aforementioned effects, share prices are also influenced by the conditions of the company itself. Factors that can affect share prices include; the company's financial condition is obtained through the company's financial statements, the deposit interest rate, the inflation rate, the amount of profit earned by the company, the marketing strategy, the level of risk, and the return on capital [44].

The stock price indicator in this study is the closing price of shares requested by the seller or buyer at the end of the stock exchange day. In such circumstances, it is possible that at the end of the stock exchange day, a share transaction suddenly occurs because there is an agreement between the seller and the buyer [45]. If this happens, the closing price will become the market price. However, this price remains the closing price on the trading day.

\section{B. Financial performance}

Financial performance as the overall financial health of the company during a certain period [46]. Financial performance is an achievement achieved by a company in a certain period that reflects the health level of the company [45]. Another scholar's view explains financial performance as a result of the work of managers in carrying out tasks assigned to those related to financial management [47]. A healthy or profitable bank financial performance will give 
rise to; creditor confidence in the bank's ability to fulfill obligations, provide guarantees to depositors about the security of their deposits, reward shareholders in exchange for invested funds, and provide job security guarantees to managers and employees, and demonstrate the bank's ability to pay taxes to the state.

Therefore, good financial performance will bring trust to stakeholders which have an impact on the increase in share prices [33]. Financial performance measurement indicators are based on company profitability which is often used to measure business success [28]. Financial performance maximizes the return on assets and maximizes shareholder benefits. Besides, profitability shows how efficiently management can generate profits by using all the resources available in the company [48].

Profitability is the center of the assessment of the existence of a company entity. This means that if the profitability is high, the lender's interest in providing loans is also high. Likewise, investors, if profitability is high, then the interest to invest is also high, this is due to investors assessment of the sustainability of the entity [49].

\section{Capital structure}

The capital structure-function is a way for companies to finance their assets to generate income and maximize shareholder wealth [50]. Sources of funds to finance bank assets can come from; first-party funds or owners (equity), second-party funds in the form of loans, and from thirdparty funds (DPK) in the form of demand deposits, savings, and time deposits. The three sources have different characteristics. One of the functions of the bank as an intermediary institution is to collect funds from the public in the form of third party funds. Third-party funds are the largest source of funds.

The greater the third party funds, the greater the bank's capital structure. The efficiency and effectiveness of bank operations are highly dependent on what shapes their capital [51]. The optimal capital structure decision allows banks to conduct bank operations successfully [52]. The capital structure provides a buffer to absorb unexpected losses from bank operations [9].

The empirical literature shows that capital structure is measured in the ratio of debt to equity. In this case, it involves the use of debt, loans, bonds, etc. Debt is a component of the capital structure expressed as the ratio of total debt to total assets. This variable has also been used as an indicator of capital structure to represent the proportion of bank or operational assets financed by debt [52].

\section{Wealth structure}

The wealth structure is one important factor because if a bank is faced with financial difficulties in paying its debts, the tangible assets or fixed assets owned by the bank can act as collateral to outsiders who make loans. Therefore, banks generally have a large number of fixed assets, because fixed assets can be used as collateral or collateral for bank loans. Tangible fixed assets used as collateral can reduce the risk of bank bankruptcy and financial difficulties to finance operational activities [53].

Banks with fast asset growth rates rely more on external funds. The higher the banking growth, the greater the need for funds to finance expansion. The greater the need for funds, the greater the desire for banks to retain profits. A growing bank should not distribute profits as dividends, but instead, use it for investment financing. If the retained earnings are not sufficient to meet the bank's funding needs, the bank concerned may use additional funds from outside the bank in the form of long-term debt.

Wealth structure can be measured by the proportion of current assets, the proportion of fixed assets, and the size of the banking company. The size of the banking company uses the benchmark of banking assets. Company management must look at the value of assets in detail because this is the basis for measuring the company's financial performance [54].

\section{E. Financial structure}

The financial structure reflects how bank assets are spent. Bank assets are funded with short-term, long-term debt, and shareholder capital, so that the entire asset side of the balance sheet shows the financial structure. It is further explained that the financial structure is reflected in the overall liabilities in the balance sheet. The financial structure also reflects the balance both in absolute and relative terms between total foreign capital (both short and long term) and the amount of capital itself [55].

Empirical factors related to a financial structure are defined as the financial condition of banks which is described based on indicators of financial structure such as; Debt to Total Assets Ratio (DAR), Equity To Asset Ratio (EAR), and Debt To Equity Ratio (DER). Debt to Total Assets Ratio (DAR) is a ratio to measure the number of assets financed by debt. This ratio is also very important to see the company's solvency. DER is a financial ratio that shows the relative proportion between equity and debt used to finance company assets and is used to measure how well the investment structure of a company is. Equity to Asset Ratio (EAR) is the proportion of funds from assets whose funding sources come from equity or shareholders.

\section{RESEARCH METHODS}

This research analyzes the effect of capital structure, wealth structure and financial structure on financial performance and stock price of the banking sector on the Indonesia Stock Exchange in 2014-2017 using quantitative methods. The research data was processed with the help of software Structural Equation Model-Smartpls-3. Data were analyzed descriptively and inferential to explain the influence or causal relationship between variables [56].

The research was conducted on banking industry companies listed on the Indonesian stock exchange. The study population includes all registered banking companies on the Indonesia Stock Exchange from 2014 to 2017. The number of listed companies is 43 banking companies multiplied by four years, bringing the total population to 172 banks. The sampling method used in this study was purposive sampling. Based on established criteria, 145 data units were obtained. 


\section{RESULTS}

Based on the results of the PLS model estimation, all indicators have a value loading factor above 0.7 so that all indicators are declared valid in measuring their constructs. Apart from looking at the value loading factor of each indicator, convergent validity is also seen from the average variance extracted (AVE) value of each construct. The PLS model is declared to have met the convergent validity if the AVE value of each constructs $>0.5$ [57].

TABLE 1: LOADING FACTOR AND AVE

\begin{tabular}{cccc}
\multicolumn{4}{c}{ TABLE 1: LOADING FACTOR AND AVE } \\
Construct & Loading Factor & Cut Value & AVE \\
\hline SP & 1.000 & 0.700 & 1.000 \\
FP1 & 0.930 & 0.700 & \\
FP2 & 0.915 & 0.700 & 0.870 \\
FP3 & 0.953 & 0.700 & \\
FS1 & 0.871 & 0.700 & \\
FS3 & 0.915 & 0.700 & 0.798 \\
WS3 & 1.000 & 0.700 & 1.000 \\
CS1 & 0.963 & 0.700 & \\
CS2 & 0.943 & 0.700 & 0.908 \\
\hline
\end{tabular}

The loading factor value of all indicators $>0.7$ and the AVE value of all constructs $>0.5$. The data shows that there is no variable indicator whose value is loading factor $<0.5$ [58]. The results of the discriminant validity test results obtained are presented as follows:

TABLE 2: DISCRIMINANT VALIDITY

\begin{tabular}{cccccc}
\hline Construct & SP & FP & FS & WS & CS \\
\hline SP & 1.000 & --- & --- & --- & -- \\
FP & 0.308 & 0.933 & --- & --- & --- \\
FS & -0.111 & -0.181 & 0.893 & --- & --- \\
WS & 0.545 & 0.351 & 0.098 & 1.000 & --- \\
CS & 0.471 & 0.255 & 0.115 & 0.958 & 0.953 \\
\hline
\end{tabular}

The results of the discriminant validity test in the table above show that all constructs have a square root value of AVE above the correlation value with other latent constructs. The calculation of discriminant validity (AVE) can be stated that each variable has good discriminant validity. This means that all indicators are declared reliable in measuring their latent variables. Thus, it can be concluded that the model has met the discriminant validity. Construct reliability can be assessed from the value Composite Reliability of each construct. Reliability test with composite reliability can be strengthened by using the Cronbach alpha of each construct. The recommended values composite reliability and Cronbach alpha > 0.7 [59].

TABLE 3: RELIABILITY

\begin{tabular}{ccc}
\hline Construct & Cronbach's Alpha & Composite Reliability \\
\hline SP & 1.000 & 1.000 \\
FF & 0.925 & 0.953 \\
FS & 0.749 & 0.887 \\
WS & 1.000 & 1.000 \\
CS & 0.900 & 0.952 \\
\hline
\end{tabular}

The reliability test results in the table above show that all constructs have a value composite reliability of $>0.7$ and Cronbach's alpha $>0.7$ which indicates that all constructs have met the required reliability. Evaluation is Path coefficient used to show how strong is the effect or influence of the independent variable on the dependent variable.

\begin{tabular}{ccc}
\multicolumn{3}{c}{ TABLE 4: PATH COEFFICIENTS } \\
\hline Construct & SP & FP \\
\hline SP & & \\
FP & 0,280 & \\
FS & $-0,093$ & $-0,313$ \\
WS & 0,086 & 0,594 \\
CS & 0,289 & $-0,071$ \\
\hline
\end{tabular}

The effect of capital structure on financial performance and share price amounted to -0.071 and 0.289 , respectively. The strength of the capital structure negatively affects financial performance is $7.1 \%$ and positively affects the stock price is $28.9 \%$. The effect of wealth structure on financial performance and share price is 0.594 and 0.086 , respectively. The strength of the financial structure affecting the financial performance was $59.4 \%$ and the share price was $8.60 \%$. The effect of financial structure on financial performance and share price is -0.313 and 0.093, respectively.

The strength of the financial structure negatively affected financial performance was $31.3 \%$ and the share price negatively was $9.30 \%$. Evaluation is indirect effects used to show the value of the relationship between the independent variable and the dependent variable.

\begin{tabular}{cc}
\multicolumn{2}{c}{ TABLE 5: INDIRECT EFFECTS } \\
\hline Path coefficients & HS \\
\hline $\mathrm{FS} \rightarrow$ FP $\rightarrow$ SP & $-0,088$ \\
$\mathrm{WS} \rightarrow \mathrm{FP} \rightarrow \mathrm{SP}$ & 0,166 \\
$\mathrm{CS} \rightarrow \mathrm{FP} \rightarrow \mathrm{SP}$ & $-0,020$
\end{tabular}

The value of the relationship between the capital structure variable and the stock price -0.020 . The negative relationship between capital structure and stock price is $2.00 \%$. The value of the relationship between the wealth structure variable and the stock price is 0.166 . The relationship between wealth structure and stock price is $16.6 \%$. The value of the relationship between the variable financial structure and the stock price is -0.088 . The negative relationship between financial structure and stock price is $8.80 \%$. After fulfilling the validity and reliability of the construct at the testing stage of the outer model, the test continues with the Goodness of Fit Model testing. The fit of the PLS model can be seen from the SMRM model value. The PLS model is declared to have met the goodness of fit model criteria if the SRMR value $<0.10$ and the model are declared perfect fit if the SRMR value $<0.08$. 


\begin{tabular}{ccc}
\multicolumn{3}{c}{ TABLE 6: FIT MODEL } \\
\hline Measurement & Saturated Model & Estimated Model \\
\hline SRMR & 0.055 & 0.055 \\
d_ULS & 0.135 & 0.135 \\
d_G & 0.288 & 0.288 \\
Chi-Square & 234.443 & 234.443 \\
NFI & 0.797 & 0.797 \\
\hline
\end{tabular}

The SRMR value of the saturated model is 0.055 as well as the SRMR value for the prediction model (estimated model) which has an SRMR of 0.055. Because the SRMR value of the saturated model and prediction model (estimated model) $<0.10$, this PLS model is declared fit, so it is suitable to be used to test the research hypothesis. The next step is to obtain the R-Square:

\begin{tabular}{cc}
\multicolumn{2}{c}{ TABLE 7: R-SQUARE } \\
\hline Variable & R-Square \\
\hline Financial performance & 0.353 \\
Stock price & 0.243 \\
\hline
\end{tabular}

The R-Square value for the financial performance variable is 0.353 . The acquisition of this value explains that the percentage of the amount of financial performance can be explained by the capital structure, wealth structure and financial structure is $35.3 \%$. The remaining $64.7 \%$ is explained by variables outside the capital structure, wealth structure and financial structure. Then for the R-Square value, the stock price variable is 0.243 . This value explains that the share price can be explained by the capital structure, wealth structure, financial structure, and financial performance by $24.3 \%$ and the remaining $75.7 \%$ is explained by variables outside the capital structure, wealth structure, financial structure, and financial performance.

The goodness of fit assessment is known from the QSquare value. The higher the Q-Square, the model can be said to be better or more fit with the data.

TABLE 8: Q-SQUARE

\begin{tabular}{cccc}
\multicolumn{4}{c}{ TABLE 8: Q-SQUARE } \\
\hline Measurement & SSO & SSE & Q $^{2}(=1-$ SSE/SSO) \\
\hline SP & 145.000 & 96.724 & 0.333 \\
FP & 435.000 & 353.768 & 0.187 \\
FS & 290.000 & 290.000 & --- \\
WS & 145.000 & 145.000 & --- \\
CS & 290.000 & 290.000 & --- \\
\hline
\end{tabular}

The Q-Square value of financial performance 0.187 . This shows the large diversity of research data which can be explained by the research model that the effect of capital structure, wealth structure and financial structure on financial performance $18.7 \%$. While the remaining $81.3 \%$ is explained by other factors of the research model.

The Q-Square value of the stock price 0.333 . This shows the large diversity of research data that can be explained by the full research model $33.3 \%$. While the remaining $66.7 \%$ is explained by other factors that are outside this research model. Thus, from these results, this research model can be stated as having a good goodness of fit.

\section{Capital structure and financial performance}

The capital structure proved to have a negative and significant effect on financial performance. This means that the higher the capital structure, the lower the banking financial performance will be. Vice versa, the lower the capital structure, the higher the bank's financial performance. A more detailed analysis by looking at the indicators of a valid capital structure, the more debt the bank has, the lower the bank's ability to produce high financial performance. The results of this study also provide information that; The capital structure of banks in Indonesia is in a less than ideal proportion as evidenced by an increase in debt that will reduce financial performance; The placement of debt in earning assets is also inaccurate, as evidenced by each increase in debt which reduces financial performance.

The effect of the capital structure variable on financial performance is -0.071 . The strength of the capital structure negatively affects financial performance is weak (7.1\%). The results of this study are in line with the findings [50] which found that companies prefer internal financing to external financing (debt). Capital structure is the company's strategy in determining the proportion of each element of capital sources to maintain financial performance [60]. But it contradicts the findings of other scholars [61] who suggest that high-performing companies tend to use more debt because of their ability to pay debts at maturity.

\section{Wealth structure and financial performance}

The wealth structure has a positive and significant effect on financial performance. This means that the higher the wealth structure, the higher the banking financial performance will be. Vice versa, the lower the wealth structure, the lower the banking financial performance will be. A more detailed analysis by looking at a valid wealth structure indicator, the greater the total assets owned by the bank will increase the bank's ability to produce high financial performance. The results of this study also provide information that; the wealth structure of banks in Indonesia is in ideal proportions as evidenced by each increase in assets that will increase financial performance. Total earning assets are quite ideal, as evidenced by each increase in assets increases financial performance. Therefore, the right placement of funding sources is needed.

The effect of wealth structure on financial performance is 0.594 . The strength of the wealth structure positively affects financial performance is strong $(59.4 \%)$. The results of this study confirm the findings of previous researchers that the wealth structure is the determination of the allocation of funds for each asset component, both in current assets and fixed assets to improve the company's financial performance [21]. The optimal bank financial structure has an impact on improving financial performance. Conversely, a non-optimal financial structure will reduce financial performance [25].

\section{Financial structure and financial performance}

The financial structure has a negative and insignificant effect on financial performance (Hypothesis is rejected). This means that the higher the financial structure does not affect the financial performance of banks. Vice versa, the lower the financial structure does not affect the financial performance of banks. A more detailed analysis by looking at indicators of a valid financial structure shows that; the higher the debt to finance assets, the lower the financial performance. The higher the proportion of debt in equity, the lower the financial performance.

The effect of financial structure on financial performance -0.313 . The strength of the financial structure negatively 
affects financial performance is strong (31.3\%). Confirming the findings of previous researchers that financing financed from leverage is inversely related to profitability. This means that funding from debt sources reduces financial performance [62]. Refute the findings [25] that an optimal financial structure can guarantee the creation of financial stability in the bank and increase financial performance. The financial structure with the DER and EAR indicators has a positive effect on financial performance [63], [64].

\section{Capital Structure and Stock Price}

The capital structure has no negative and significant effect on stock prices. This means that the higher the capital structure, the lower the stock price of banks. Vice versa, the lower the capital structure will not increase the bank's share price. A more detailed analysis by looking at valid indicators of capital structure, the more debt the bank has does not reduce the stock price. The results of this study also provide information that: The capital structure of banks in Indonesia is considered by investors to be in a reasonable proportion, as evidenced by an increase in debt that does not reduce stock prices.

The use of debt as a source of funding is not viewed by investors as a negative thing, which is proven that any increase/decrease in debt does not affect share prices. Investors assume that the invested funds will be used to substitute debt to share capital or for investment development. The effect of capital structure on stock prices is 0.289 . The strength of the capital structure positively affects financial performance is strong (28.9\%). This finding explains that $28.9 \%$ of investors' considerations in investing originate from information on capital structure.

Confirming the findings [65] that the capital structure model or the use of debt is a signal that is conveyed by managers to the market. If the manager has confidence that the company's prospects are good and wants the stock price to increase, the manager will communicate this to investors. Capital structure is the company's strategy in determining the proportion of each element of capital sources to maintain financial performance and share prices [60], [66]. Highperforming firms tend to use more debt because of their ability to pay debts at maturity [61].

The results of this study were rejected (according to the hypothesis) by previous researchers [67] that the capital structure partially has a negative effect on stock prices in manufacturing companies listed on the Indonesia Stock Exchange. This means that the use of sources of funds in the form of providing assets of high value will increase the fixed burden that will be borne by the company. The consequences of large total assets are; the bank's ability to generate operating profit becomes smaller, the company's value will decrease, and in turn, will affect the stock price. Companies prefer internal financing to external financing [50].

\section{Wealth Structure and Stock Price}

The wealth structure proved to have a positive and significant effect on stock prices. This means that the higher the wealth structure, the higher the bank share price will be. Vice versa, the lower the wealth structure, the lower the banking financial performance will be. A more detailed analysis by looking at indicators of valid wealth structure, the greater the total assets owned by the bank will increase the bank's ability to raise the share price. The results of this study provide information that; the wealth structure of banks in Indonesia is in ideal proportions as evidenced by each increase in assets that will increase the share price.

Total productive assets are quite ideal, as evidenced by each increase in assets increases the share price. Therefore, the placement of funding sources has strategic value. The effect of the wealth structure on stock prices 0.086. The strength of the wealth structure positively affects the share price $8.60 \%$. The results of this study are in line with the findings of previous researchers, that the factors that can affect stock prices include; the company's financial condition is obtained through the company's financial statements, the deposit interest rate, the inflation rate, the amount of profit earned by the company, the marketing strategy, the level of risk, and the return on capital [44].

In contrast to the findings of other researchers, the wealth structure partially has a negative effect on stock prices in manufacturing companies listed on the Indonesia Stock Exchange [67]. This means that the use of sources of funds in the form of providing assets of high value will increase the fixed burden that will be borne by the company. The consequences of large total assets are; the bank's ability to generate operating profit becomes smaller, the company's book value will decrease, and in turn, will affect the stock price.

\section{Financial Structure and Stock Price}

Financial structure has a negative and significant effect on stock prices. This means that the higher the financial structure, the lower the bank's stock price will be. Vice versa, the lower the financial structure, the higher the bank's share price. A more detailed analysis by looking at indicators of a valid financial structure shows that; the higher the debt to finance assets, the lower the share price. The higher the proportion of debt to equity, the lower the share price. The effect of the financial structure on the share price -0.093 . The strength of the financial structure negatively affects the share price $9.30 \%$.

The results of this study are in line with other researchers [68]-[70] who found the information presented in the company's financial statements to be a signal for investors to make investment decisions. Relevant and reliable information is needed for investors as an analytical tool in making investment decisions. When published information contains positive values, market trends will react positively.

\section{Financial Performance and Stock Prices}

Financial performance on stock prices is not proven to have a positive and significant effect on stock prices. This means that the high financial performance generated by the banking industry is not the cause of the increase in stock prices. Vice versa, the decline in banking financial performance is not the cause of the decline in bank share prices. A more detailed analysis by looking at valid financial performance indicators, namely Return on Assets (ROA), Return on Equity (ROE), and Net Profit Margin (NPM) obtained by the banking industry does not necessarily respond positively by investors which can raise stock prices.

The results of this study also provide information that the bank's ability to return investment, the ability to return capital, and a large gross profit margin are not seen as attractive by investors, so they are not responded positively. 
As a result, share prices remain stagnant. This can be seen from the insignificant effect of financial performance on share prices. The effect of the variable financial performance on stock prices 0.280 .

The strength of financial performance positively affects the stock price is $28.00 \%$, but it is not able to influence the stock price (insignificant). The results of this study reject previous findings [65] that the signal sent by managers to the capital market in the form of good company prospects aims to increase stock prices. Investors are expected to catch these signals as a signal that the company has good prospects and has an impact on rising stock prices. Also rejecting the findings of other studies [68]-[70], when financial information contains a positive value (good news) is published, the capital market trend will react positively, or stock prices will rise. The underlying concept is that the value of the company's shares is influenced by the company's financial performance.$$
\begin{aligned}
& \text { 8. Cal } \\
& \text { Price }
\end{aligned}
$$

8. Capital Structure $\rightarrow$ Financial Performance $\rightarrow$ Stock

The capital structure on stock prices mediated by financial performance show that the variable relationship value is -0.020 . The negative relationship between capital structure and share price, which is mediated by financial performance, $2.00 \%$. The small value of the indirect relationship between capital structure and stock prices indicates a small role in financial performance as a mediating variable. The results of this study provide information that the direct effect of capital structure on stock prices is stronger than the indirect effect of capital structure on stock prices through financial performance. The relationship between the capital structure variable and the stock price 0.289 or the positive relationship between capital structure and stock price $28.90 \%$.

The results of the indirect effect of capital structure on stock prices mediated by financial performance supports the study [71]; the capital structure has an indirect effect on firm value with profitability as an intervening variable. Capital structure has a positive indirect effect on stock prices [63]. Capital structure has a positive effect on stock prices through company performance [72].

The results of hypothesis testing reject trade-off theories in which the determination of the company's capital structure considers the benefits and tradeoffs that arise as a result of the use of debt by the company. One of the benefits arising from the use of debt is that the company can improve performance by utilizing the availability of sufficient funds obtained through debt. However, the results of hypothesis testing indicate that financial performance does not mediate the effect of capital structure on stock prices. He also rejects the signaling theory which discusses those positive signals about the company's financial performance and future growth of the company can increase stock prices.

\section{Wealth Structure $\rightarrow$ Financial Performance $\rightarrow$ Stock Price}

The direct effect of wealth structure on stock prices is weaker than the indirect effect of wealth structure on stock prices through financial performance. The value of the relationship between the wealth structure variable and the stock price 0.086 or the positive relationship between the wealth structure and the stock price $8.60 \%$. Even though the wealth structure on stock prices through financial performance is stronger than the direct effect of wealth structure on stock prices, but the effect of financial performance on stock prices is not significant, it is concluded that financial performance does not mediate wealth structure on share prices.

The results of the study of the indirect effect of wealth structure on stock prices mediated by financial performance support [71] that wealth structure has a positive indirect effect on firm value with profitability (financial performance) as an intervening variable. Capital structure has a negative indirect effect on stock prices which is mediated by financial performance [63].

Inconsistent with findings [73] that indirect capital structure to the stock price that is mediated by the financial performance is a negative influence. The results of hypothesis testing reject the trade-off theories in which the determination of the wealth structure considers the benefits and tradeoffs that arise as a result of the placement of sources of funds from the capital and debt for current assets and bank fixed assets. The benefits arising from the correct placement of funds in assets can improve financial performance which has an impact on share prices.

However, the results of hypothesis testing reject the role of financial performance as a mediating variable. He also rejects the signaling theory which discusses those positive signals about the company's financial performance and future growth of the company can increase stock prices.

\section{Financial Structure $\rightarrow$ Financial Performance $\rightarrow$}

\section{Stock Price}

The value of the indirect relationship between the wealth structure and the stock price which is mediated by financial performance is 0.166. This means that the positive relationship between wealth structure and stock prices mediated by financial performance is $16.00 \%$. This shows the value of the indirect relationship of wealth structure to stock prices, indicating that the role of financial performance as a mediating variable is very small.

The results of this study provide information that the direct effect of financial structure on stock prices is stronger than the indirect effect of financial structure on stock prices through financial performance. The value of the relationship between financial structure variables and stock prices is 0.093 or the negative relationship between financial structures and stock prices [74], [75] that there are stocks is $9.30 \%$.

Meanwhile, the value of the indirect relationship between financial structure and stock prices 0.088 or the positive relationship between financial structure and stock prices $8.80 \%$. Even though the financial structure on stock prices through financial performance has the effect of $8.80 \%$, but the effect of financial performance on stock prices is insignificant, it is concluded that financial performance does not mediate the financial structure on stock prices.

The indirect effect of the financial structure of the share price that is mediated by financial performance to support the study (negative influence on relations financial structure to the stock price that is mediated by the performance of the company. But the rejection of the findings [76] which found that no indirectly financial structure of share prices mediated by financial performance Hypothesis testing results reject 
trade-off theories in which the determination of financial structure considers the benefits and sacrifices that arise as a result of the placement of sources of funds from the capital and debt for current assets and bank fixed assets. However, the results of hypothesis testing reject the role of financial performance as a mediating variable.

This research finding rejects the signaling theory which discusses the positive signal about the company's financial performance and company growth in the future. The optimal financial structure can increase profitability and have an impact on increasing share prices. High profitability information is seen as a good signal for investors. If the company can increase high profitability, then the demand for shares will increase and will have an impact on increasing share prices.

\section{CONCLUSIONS AND RECOMMENDATIONS}

Capital structure is a negative effect on financial performance. The more debt the bank has, the lower the bank's ability to produce high financial performance. The capital structure of banks in Indonesia is still dominated by debt and the placement of funds in productive assets has not been optimal. Cannot take advantage of the potential use of money to improve financial performance. The wealth structure has a positive effect on financial performance. This is because the total assets owned by banks in Indonesia can increase the ability of banks to produce high financial performance.

The wealth structure of banking in Indonesia reflects an optimal proportion so that it can take advantage of the potential from the allocation of assets or assets that can improve financial performance. This study rejects the hypothesis that financial structure has a negative and significant effect on financial performance. The results of the analysis are in line with the hypothesis but not significant. The debt to equity and debt to assets ratio is not too extreme so that it does not affect the rise/fall of financial performance.

This study rejects the hypothesis that capital structure has a negative and significant effect on stock prices. The results of the analysis are in line with the hypothesis but not significant. This is due to the view of investors that the capital structure of banking in Indonesia is within reasonable limits. Investors feel confident in management that funds originating from debt can be managed properly. Both of these have been responded positively by investors so that they are not a major consideration in investing.

The wealth structure has a positive effect on stock prices. The higher the value of assets owned by the bank, the higher the share price. This is due to the provision of high-value productive assets which will increase the bank's ability to generate high operating profits which will have an impact on the positive response of investors to buy stocks at a higher price.

The financial structure is a negative effect on stock prices. This is due to the high ratio of debt to assets and the ratio of debt to equity. Investors responded negatively to this ratio, thereby lowering stock prices. This study rejects the hypothesis that financial performance has a positive effect on stock prices. Information about Return on Assets (ROA),
Return on Equity (ROE) and Net Profit Margin (NPM) has not been responded positively by investors. Even though the strength of financial performance represented by the three ratios is $28 \%$ affecting stock prices, it has not been able to make stock price movements more dynamic.

This study rejects the hypothesis that financial performance mediates the effect of capital structure on stock prices. The results showed a weak relationship between the variables of capital structure, financial performance, and stock prices. It is emphasized that there is no influence on financial performance on share prices. Therefore it is concluded that financial performance does not mediate the effect of capital structure on stock prices.

This study rejects the hypothesis that financial performance mediates the effect of wealth structure on stock prices. The results showed a weak relationship between the variables of wealth structure, financial performance, and stock prices. It is emphasized that there is no influence on financial performance on share prices. Therefore it is concluded that financial performance does not mediate the effect of wealth structure on stock prices.

This study rejects the hypothesis that financial performance mediates the effect of financial structure on stock prices. The results showed a weak relationship between the variables of financial structure, financial performance, and stock prices. It is emphasized that there is no influence on financial performance on share prices. Therefore it is concluded that financial performance does not mediate the financial effect on stock prices.

This study provides support for the theory of Balanced Theory, Trade-off Theory, and Signaling Theory, as well as enriching the literature and developing financial management studies by providing empirical evidence of the factors that influence financial performance and stock prices. These findings strengthen the theoretical model conceptualized [25].

The optimal bank financial structure has an impact on improving financial performance. The information presented in the company's financial statements is a signal for investors in making investment decisions [68,69]. But it does not strengthen the theoretical model conceptualized $[68,69]$ that the value of the company's shares is influenced by the company's financial performance. Recommendations to the government (regulator) can be used as input in the framework of issuing standards that can strengthen the capital structure, wealth structure, and financial structure.

Empirical evidence shows that decisions on capital structure, wealth structure, and optimal financial structure are important issues that must be paid attention to by banking management. Capital structure, wealth structure, and financial structure affect financial performance and share prices. However, financial performance is not one of the information considered by investors in making investment decisions in banking.

Recommendations to the entity can be used as input in responding to the need for a balance of capital structure, wealth structure, and financial structure within the bank to achieve high financial performance and share prices. Limitations of this study, the results of the $\mathrm{R}$ square test in this study have a low value.

This means that many other variables have not been tested 
in this study that can affect financial performance and stock prices. It is proven in this research; only capital structure and wealth structure affect financial performance; only the wealth structure and financial structure affect the share price. Besides, the data source used is very limited and the observational data is very extreme, so it is suggested to further researchers to; adding other variables that are likely to affect financial performance and share prices; changing indicators for measuring capital structure, wealth structure, financial structure, financial performance, and stock prices to get better results; and increase the years of observation.

\section{REFERENCES}

[1] De Bandt, O., Camara, B., Pessarossi, P., and Rose, M. (2014). Débats économiques et financiers N 12.

[2] Scott, S. M., and Timothy, W. K. (2006). Management of Banking, Thomson/South-Western.

[3] Ronoh, C. and Ntoiti, J. (2015). Effect of Capital Structure on Financial Performance of Listed Commercial Banks in Kenya. A Case Study of Kenya Commercial Bank Limited. The Strategic Journal of Business \& Change Management, 2(72), 750-781.

[4] Paramasivan, C. and Subramanian, T. (2009). Financial Management. New Delhi: New Age International Pvt Ltd.

[5] Ganiyu, Y. O. (2015). Dynamic Analysis of the Impact of Capital Structure on Firm Performance in Nigeria. (PhD), De Montfort, United Kingdom

[6] Njeri, M. M. and Kagiri A. W. (2015). Effect of Capital Structure on Financial Performance of Banking Institutions Listed in Nairobi Securities Exchange.International Journal of Science and Research. 4(7), 924-930.

[7] Anarfo, E. B. (2015). Determinants of capital structure of banks: evidence from sub-sahara africa, Asian Economic and Financial Review, 5(4) 624-640.

[8] Allahham, M. (2015). Impact of Capital Structure on Bank Financial Performance of Al Ahli Bank in Saudi Arabia. Global Journal of Management and Business research: Corporate Finance., 15(9).

[9] Aremu, M.A., Ekpo, I.C. and Mustapha, A.M., (2013). Determinants of Banks' Profitability in a Developing Economy: Evidence from Nigerian Banking Industry. Interdisciplinary Journal of Contemporary Research in Business, 4 (9), 155-181.

[10] Adah, A. (2012). Impact of Recapitalisation on the Financial Performance of Deposits Money Banks in Nigeria (PhD Accounting \& Finance), ABU, Zaria.

[11] Martias A, (2017). Analysis of Company Financial Performance with Determinant Ratio Approach in the Indonesia Stock Exchange, Monetary Journal, 7 (4), 96-105.

[12] Kundakchyan, R. and Zulfakarova, L. (2014). Current issues of optimal capital structure based on forecasting financial performance of the company. Life Science Journal, 11 (6), 368-371.

[13] Al-Tally, H. (2014). An Investigation of the Effect of Financial Leverage on Firm Financial Performance in Saudi Arabia's Public Listed Companies. (Doctor of Business Administration), Victoria Melbourne, Australia.

[14] Goyal, A. M. (2013). Impact of Capital Structure on Performance of Listed Public Sector Banks in India. International Journal of Business and Management Invention, 2(10), 35-43.

[15] Mirza, S. A. and Javed, A. 2013. Determinants of financial performance of a firm: Case of Pakistani stock market. Journal of Economics and International Finance, 5,(2), 43-52.

[16] Modigliani, F., and M. H. Miller. (1963). Corporate Income Taxes and The Cost of Capital: A Correction. The American Economic Review 53 (3), 433-443.

[17] Younus, S., Ishfaq, K., Usman, M. and Azeem, M. (2014). Capital Structure and Financial Performance: Evidence from Sugar Industry in Karachi Stock Exchange Pakistan. International Journal of Academic Research in Accounting, Finance and Management Sciences, 4 (4), 272-279.

[18] Ramadan, Z. S. and Ramadan, I. Z. (2015). Capital Structure and Firm's Performance of Jordanian Manufacturing Sector. International Journal of Economics and Finance, 7 (6). 279-284.

[19] Khan, M., Sajid, M., Waseem, M. and Shehzad, M. (2016). Capital Structure Composition Demeanour towards Corporate Financial Performance Potential. International Journal of Innovation and Applied Studies, 14 (1), 210-217.
[20] Watson, D. and Head, A. (2007). Corporate Finance: Principle \& Practice (4th ed.). Harlow, England: Prentice Hall Financial Times.

[21] Syamsudin. L. (2017). Corporate Financial Management: Application Concepts in Planning, Supervision, and Decision Making. New edition. Jakarta: PT. Raja Grafindo Persada.

[22] Gohar, R. and Shoaib, A. (2011). Achieving the Optimal Capital Structure and its Impact on Pakistani Banking Performance International Review of Business Research Papers, Vol. 7(3), 9-24.

[23] Nunky Rizka Mahapsari, NR (2013). The Effect of Profitability, Asset Structure, and Sales Growth on Stock Prices with Capital Structure as an Intervening Variable in Manufacturing Companies on the Indonesia Stock Exchange, Nominal Journal, 2 (1), 237-158.

[24] Sawir. A. (2018). Financial performance analysis and corporate financial planning. Jakarta: Gramedia Pustaka Utama.

[25] Fraser, D. R., Zhang, H., and Derashid, C. (2006). Capital structure and political patronage: The case of Malaysia. Journal of Banking \& Finance, 30(4), 1291-1308.

[26] Weston, JF, and Copeland, TE (2016). Financial Management, Edition-8, Translator Kirbrandoko, A. Jaka Wasana M, and Supranoto Dipokusumo. Jakarta: Erlangga Publisher.

[27] Meivinita, (1998), Analysis of Several Variables Affecting the Financial Structure of Hospitality Service Companies Going Public in Indonesia), Thesis, Postgraduate Program, Brawijaya University Malang.

[28] Monica, M., Sulistyani, L., and Nurdyastuti, T. (2018). The effect of capital structure on return on equity of food and beverage companies listed on the Indonesian stock exchange for the 2014-2016 period. Actual, 3 (2).

[29] Amin, S., and Jamil, T. (2015). Capital structure and firm performance: Evidence from cement sector of Dhaka stock exchange limited. Journal of Finance and Banking, 13(1), 29-42.

[30] Alipudin, A and Oktaviani, R. (2016). Effect of EPS, ROA, and DER on Stock Prices in Cement Sub-Sector Companies Listed on the Indonesian Stock Exchange. Scientific Journal of Accounting, Faculty of Economics, 2, (1), 1-22.

[31] Damayanti, R and Valianti, RM (2016). Effect of Debt to Assets Ratio, Debt to Equity Ratio, Return on Assets and Net Profit Margin on Stock Prices in LQ-45 Index Companies on the Indonesia Stock Exchange. Wahana Ekonomika Media Journal, 13, (1), 16 - 36.

[32] Agustanto, H and Sunarjanto. (2009). Asset Structure, ROA, Company Size, BVES, EPS, and Company Value. Journal of Business and Management, 9 (2).

[33] Aymen, B. M. (2013). Impact of capital on financial performance of banks: the case of Tunisia. Banks and Bank Systems, 8( 4). 47-54.

[34] Hidayat, D. and Topowijono. (2018). The Influence of Financial Performance on Stock Prices (Studies on Mining Companies in the Oil and Gas Mining Sub-Sector Listed on the Indonesia Stock Exchange for the Period 2013-2016). Journal of Business Administration. 62 (1), 36-44.

[35] Gatiningsih, S. (2009). Effect of Return on Assets, Return on Equity, and Debt to Equity Ratio on Stock Prices in Food and Beverage Companies listed on the Indonesian Stock Exchange, USU's Journal of Accounting.

[36] Kusumawardani, A. (2010). Analysis of the effect of EPS, PER, ROE, FL, DER, CR, ROA on stock prices and their impact on the performance of LQ45 companies listed on the Indonesian stock exchange for the period 2005-2009: Faculty of Economics, Gunadarma University.

[37] Bringham, E.F and Houston, JF (2012). Fundamentals of Financial Management. Jakarta: Four Salemba.

[38] Ardimas, W., and Wardoyo, W. (2015). The Influence of Financial Performance and Corporate Social Responsibility on Company Value at Go Public Banks Registered in Indonesian Stock Exchange. Benefit: Journal of Management and Business, 18 (1), 57-66.

[39] Repi, S., Murni, S., and Adare, D. (2016). Factors that affect the value of the banking subsector firm on the Indonesian stock exchange in facing the AEC. Journal of EMBA: Journal of Economic Research, Management, Business and Accounting, 4 (1).

[40] Suad. H. (2018). Financial Management Theory and Application. Yogyakarta: BPFE - Edition 4.

[41] Jogiyanto. H. (2018). Data Collection Methods and Analysis Techniques. Master of Science and Doctoral Program at Gadjah Mada University.

[42] Sartono, A. (2001). Financial Management Theory and Applications. Yogyakarta: BPEF-Yogyakarta.

[43] Natarsyah. S. (2000). Analysis of the Influence of Several Fundamental Factors and Systematic Risk on Stock Prices in the Case of Go-Public Consumer Goods Industry in the Indonesian Capital Market. Journal of Indonesian Economy and Business. 15 (3), 294 312. 
[44] Ratih, D., Apriatni EP, and Saryadi. (2013). Effect of EPS, PER, DER, ROE on Stock Prices in Mining Companies listed on the Indonesian Stock Exchange 2010-2012. Diponegoro Journal of Social and Politic, 1-12.

[45] Sutrisno. (2009). Financial Management Theories, Concepts and Applications. Yogyakarta: Econisia.

[46] Bhunia, A., Mukhuti, S., and Roy, S. (2011). Financial Performance Analysis-A Case Study. Current Research Journal of Social Sciences, 3(3), 269-275

[47] Fahmi, I. (2018). Financial Statement Analysis, Bandung: Alfabeta.

[48] Chakravarthy, B. S. (1986). Measuring Strategic Performance. Strategic Management Journal, 7, 437-458.

[49] Banerjee, A. and De, A. (2014). Determinants of Corporate Financia Performance Relating to Capital Structure Decisions in Indian Iron and Steel Industry: An Empirical Study. Paradigm, 18 (1), 35-50.

[50] Ningi S. I., and Usman H. A. (2017). Nigerian Journal of Management Technology \& Development, 8 (1), 124 - 135.

[51] Adha, C., and Dewi, FR (2014). Effect of Financial Performance on Stock Prices of Cable Manufacturing Companies Listed on the Indonesia Stock Exchange. Journal of Management and Organization, 5 (1).

[52] Gebremichael, F. G. (2016). The Impact of Capital Structure on Profitability of Commercial Bank of Ethiopia. Journal of Poverty, Investment and Development, 28, 17-36.

[53] Indrajaya, G., Herlina., And Setiadi, R. (2011). The Influence of Asset Structure, Company Size, Growth Rate, Profitability and Business Risk on Capital Structure: Empirical Study of Mining Sector Companies Listing on the Indonesia Stock Exchange 2004-2007 Period. Accurate Scientific Journal of Accounting, 2 (6).

[54] Weston, J. F., and Brigham, E. F. (2005). Intermediate Financia Management. The Dryden Press

[55] Riyanto, Bambang. (2018). Financial management. BPFE. Yogyakarta.

[56] Ferdinand. A. (2006). Management Research Methods: Research Guidelines for Thesis, Thesis and Management Science Dissertation. Semarang: Diponegoro University.

[57] Ghozali, I. (2008). Structural Equation Modeling: Alternative Model with Partial Least Square. Publishing Agency of Diponegoro University, Semarang.

[58] Ghozali, I. (2013). Multivariate Analysis Application with IBM SPSS 21 Update PLS Regression Program. Semarang: Diponegoro University Publishing Agency.

[59] Eisingerich, A. B., and Rubera, G. (2010). Drivers of brand commitment: A cross-national investigation. Journal of International Marketing, 18(2), 64-79.

[60] Nurhikmah, D. (2013). Leverage Influences on Firm Value in Manufacturing Industry Going Public in Indonesia. EMBA Journal, 1 (3). 1-19.

[61] Myers, S. C. and Majluf, N. S. (1984). Corporate Financing and Investment Decisions when Firms Have Information that Investors Do Not Have. Journal of Financial Economics, 13, 187-221.

[62] Megginson W. (1977). Corporate Finance Theory, Addison Weley Educational Publisher, Inc.

[63] Binangkit, AB and Sugeng Raharjo, S. (2014). Effect of Capital Structure on Company Performance and Stock Prices in Manufacturing Companies on the Indonesia Stock Exchange, Actual, 1 (2). 24-26

[64] Ross S. (1977). The Determination of Financial Structure: The Incentive Signalling Approach", The Bell Journal of Economics, 8 (1), 23-40.

[65] Mahapsari, N. R, and Taman, A. (2013). The Effect of Profitability, Asset Structure, and Sales Growth on Stock Prices with Capital Structure as an Intervening Variable in Manufacturing Companies on the Indonesia Stock Exchange. Nominal Journal, 3 (1)

[66] Vice, LRS, and Lauw, TT (2011). The Effect of Current Ratio, Earnings per Share, and Price Earnings Ratio on Stock Prices. Journal of Accounting, 3 (2), 136 - 158.

[67] Scott, H. S. (2009). International finance: transactions, policy, and regulation. Foundation Press.

[68] Hamidi, RR (2014). The Effect of Capital Structure on Firm Value with Profitability as an Intervening Variable in Property and Real Estate Companies on the Indonesia Stock Exchange. Denpasar: Thesis. Udayana University.

[69] Afriano, T., and Nikmah, N. (2016). Relationship of Capital Structure, Company Performance and Share Prices in Property and Real Estate Companies Listed on the Indonesia Stock Exchange. Journal of Accounting, 6 (2), 157-172.

[70] Nelwan, R., Sjahruddin, H., and Sohilauw, MI (2020). Effect of Profitability and Solvency on Manufacturing Company Stock Prices.
Indonesian Journal of Management and Business Science, 10 (1), 10 17.

[71] Anggraeni, IR, Sjahruddin, H., and Astuti, NP (2020). Effect of Profitability and Liquidity on Stock Prices in Food and Beverage Companies. Indonesian Journal of Management and Business Science, 10 (1), 1-9.

[72] Sulistiawati, D., and Sjahruddin, H. (2020). The Effect of Earning Per Share and Dividend Per Share on Stock Prices of Companies in the Property, Real Estate and Construction Sector Companies Listed in the Indonesian Stock Exchange. Journal of Administration and Management, 10 (1), 77-84.

[73] Asaala, M., Rasuli, L., and Monoarfa, Valentina. (2014). The Effect of Capital Structure on Firm Value with Return On Assets as an Intervening Variable (Case Study of Manufacturing Companies Listed in Indonesian Stock Exchange 2011-2013. Article. State University of Gorontalo.

[74] Alozzi, N. M., and Obiedat, G. S. (2016). The Relationship Between the Stock Return and Financial Indicators (Profitability, Leverage) An Empirical Study on Mnufacturing Companies Listed in Amman Stock Exchange. Journal of Social Sciences, 15, 408-424.

[75] Banerjee, S., and Bandyopadhyay, G. (2016). A Post Factor Analysis of Financial Ratios of Selected IPOs and its Impact on Grading: An Empirical Inquest. Journal of Business Studies Quarterly. 8, 23-34.

[76] Mustaqim, M. (2020). Effect of ROE, DAR, DER, EAR on ROA with NPM and CSR as intervening variables. JIMMU (Journal of Management Sciences), 5 (1), 81-92. 